\title{
Pitriyazis Likenoides et Varioliformis Akuta (PLEVA): Olgu Sunumu
}

\author{
Aslı Aksu Çerman ${ }^{1}$, Janset Erkul Arıcı', ilknur Kıvanç Altunay ${ }^{1}$, Özben Yalçın²
}

\begin{abstract}
ÖZET:
Pitriyazis Likenoides et Varioliformis Akuta (PLEVA): Olgu sunumu

Pitriyazis likenoides et varioliformis akuta (PLEVA), ani başlayan, etyolojisi tam olarak bilinmeyen yaygın papüloskuamöz lezyonlar ile karakterize bir deri hastalığıdır. Burada özellikle fleksural alanlarda yoğunlaşan, yer yer nekrotik krutlu yaygın papüloskuamöz lezyonlar ile birlikte, ateş, halsizlik ve kas ağrıları olan 31 yaşında nörofibromatozisli bir PLEVA olgusu sunulmaktadır.

Anahtar kelimeler: Pitriyazis likenoides et varioliformis akuta

\section{ABSTRACT:}

Pityriasis Lichenoides et Varioliformis Acuta (PLEVA): case report

Pityriasis lichenoides et varioliformis acuta (PLEVA), is a sudden onset skin disease characterized by diffuse papulosquamous lesions with unknown etiology. Here, we report a 31-year-old patient with neurofibromatosis who had generalised papulosquamous lesions especially on flexural areas, accompanying fever, malaise and muscle pain.

Key words: Pityriasis lichenoides et varioliformis acuta
\end{abstract}

Ş.E.E.A.H. Tıp Bülteni 2015;49(3):214-7

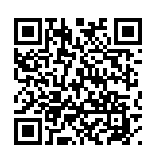

'Şişli Hamidiye Etfal Eğitim ve Araştırma Hastanesi, Dermatoloji Kliniği, İstanbul-Türkiye ${ }^{2}$ Şişli Hamidiye Etfal Eğitim ve Araştırma Hastanesi, Patoloji Kliniği, İstanbul-Türkiye

Yazışma Adresi / Address reprint requests to: Aslı Aksu Çerman,

Şişli Hamidiye Etfal Eğitim ve Araştırma Hastanesi, Dermatoloji Kliniği, İstanbul-Türkiye

Telefon / Phone: +90-542-619-6919

Faks / Fax: +90-212-224-0772

E-posta / E-mail:

aksuasli@hotmail.com

Gelis tarihi / Date of receipt:

14 Ağustos 2014 / August 14, 2014

Kabul tarihi / Date of acceptance: 14 Kasım 2014 / November 14, 2014

\section{GíRiş}

Pitriyazis Likenoides et Varioliformis Akuta (PLEVA), deride yaygın eritemli skuamlı papüllerle karakterize, sıklıkla hemorajik ve papülonekrotik lezyonların da eşlik ettiği, ani başlangıçlı bir deri hastalı̆̆ıdır (1). Etyolojisi kesin olarak bilinmemekle birlikte ilaçların ve enfeksiyöz ajanların tetikleyici olabileceği düşünülmektedir (2). Febril ülseronekrotik MuchaHabermann Hastalığı (FUMHH), Degos ve ark. (3) tarafından 1966 yılında tanımlanmış, nadir görülen ve bazen ölümcül olabilen PLEVA formudur. Klinik olarak PLEVA'dan ülseronekrotik deri lezyonlarının baskın olması, yüksek ateş, karın ağrısı, diyare, artrit, akciğer tutulumu ve santral sinir sistemi semptomlarının eşlik edebilmesi ile ayrılır $(4,5)$. Burada, ateşin eşlik ettiği ve oral tetrasiklin tedavisine iyi yanıt veren bir PLEVA olgusu sunulmaktadır.

\section{OLGU}

Polikliniğimize başvuran 31 yaşında erkek hastanın halsizlik ve kas ağrısı şikayeti ile birlikte 2 hafta önce başlayan, gövde ve ekstremitelerinde özellikle fleksural alanlarda yoğunlaşan yer yer nekrotik krutlu yaygın papüloskuamöz döküntüsü mevcuttu (Resim 1,2). Döküntüler oluşmadan önce herhangi bir ilaç kullanımı veya geçirilmiş enfeksiyon öyküsü yoktu. Özgeçmişinde Nörofibromatozisi olan hasta sağ yanaktaki dev nörofibrom nedeniyle 3 kez opere edilmişti ve yüzün sağ tarafında postoperatif gelişen fasiyal paralizi mevcuttu. Sistemik muayenede bölgesel lenfadenopati saptanmadı. Hastanın hemogram ve biyokimya tetkikleri normaldi. Hepatit B, hepatit C, Epstein-Barr virüsü, sitomegalovirüs, HIV ve sifiliz serolojisi negatifti. Hastadan alınan punch biyopsinin histopatolojik incelemesinde yüzeyde parakeratoz, 


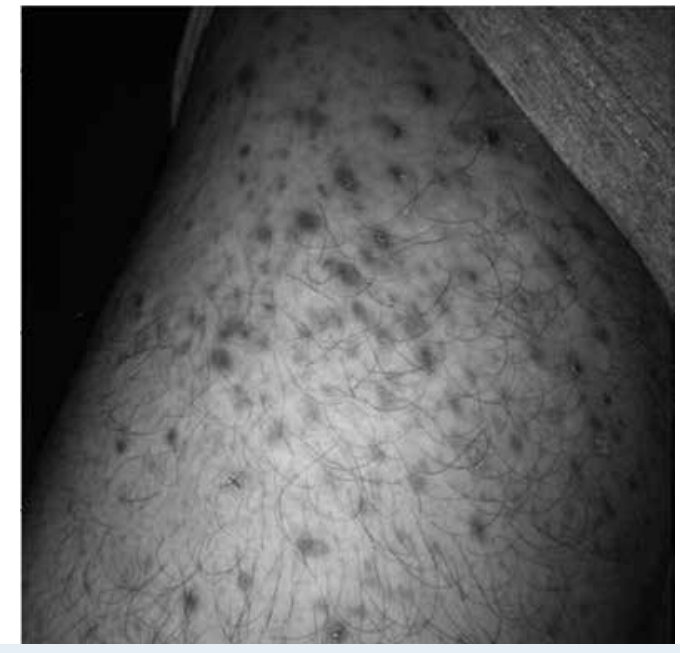

Resim 1: Sağ uylukta eritemli, bazılarının üzeri nekrotik kurutlu papüller

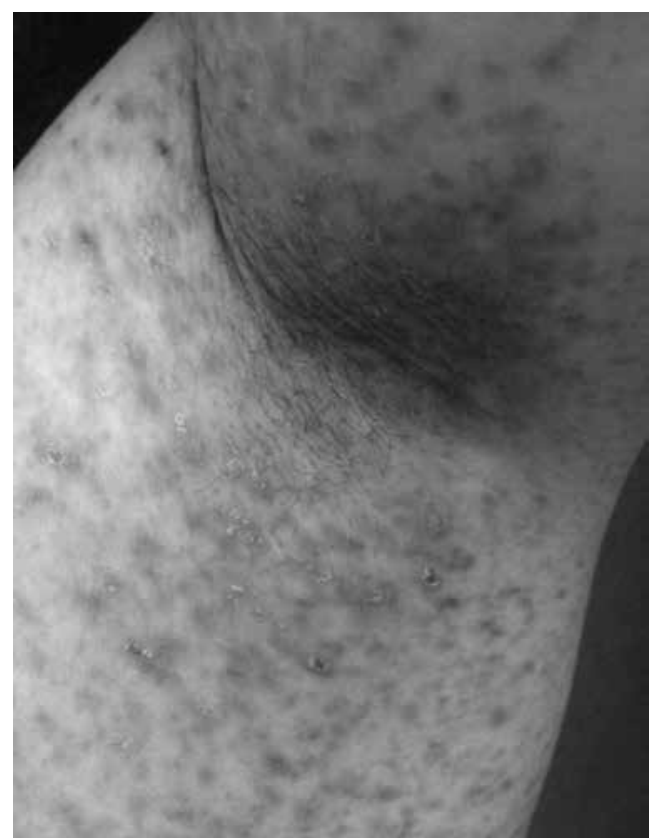

Resim 2: Sol aksiller bölgede eritemli, yer yer kurutlu papüller

lenfosit kümeleri, ekzositoz, fokal spongioz, nekrotik keratinositler, eritrosit ekstravazasyonu, bazal tabakada vakuolar değişiklikler ve lenfoid likefaksiyon görüldü, atipik lenfositler izlenmedi. Dermiste perivasküler interstisyel nadir eozinofil de içeren lenfositik infiltrasyon ve eritrosit ekstravazasyonu izlendi (Resim 3). Olguya klinik ve histopatolojik bulgular doğrultusunda PLEVA tanısı kondu. Hastaya $0.5 \mathrm{mg} / \mathrm{kg} /$ gün prednisolon ile birlikte semptomatik tedavi başlandı. Yatı-

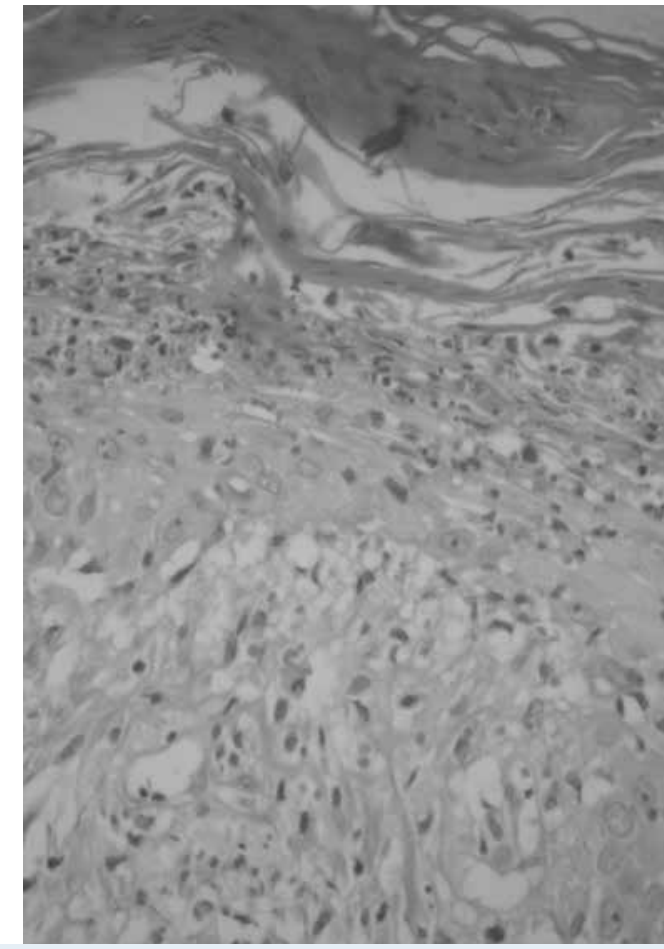

Resim 3: Epidermiste parakeratoz, lenfosit kümeleri, ekzositoz, nekrotik keratinositler, eritrosit ekstravazasyonu, bazal tabakada vakuolar değişiklikler, dermiste perivasküler interstisyel nadir eozinofil de içeren lenfositik infiltrasyon ve eritrosit ekstravazasyonu (HE x 200).

şının 4.gününde ateşi $39^{\circ} \mathrm{C}^{\prime}$ ye yükseldi. C-reaktif protein ve akciğer grafisi normaldi, lökositozu yoktu. Kan ve idrar kültürü alındı. İdrar kültüründe üreme olmadı. Kan kültüründe metisiline hassas staphylococcus aureus (MSSA) üremesi tespit edildi. Hastada odak saptanması açısından tüm batın ultrasonografi ve ekokardiyografi incelemeleri yapıldı, abse veya endokardit ile uyumlu bulgu saptanmadı. Yatışının 9. gününde ateşi tekrar $40^{\circ} \mathrm{C}^{\prime}$ ye yükselen hastanın bu ateşli dönemde bacaklar ve ayak sırtlarında daha önce lezyon olmayan bölgelerde yeni papuloskuamöz lezyonlar oluştu. Hastadan tekrar kan kültürü alındı ve yine MSSA üremesi olması üzerine sistemik prednisoIon tedavisi kesilerek iv ampisilin+sulbaktam tedavisi başlandı, 10 gün tedaviye devam edildi. Bakteriyeminin periferik iv katater kaynaklı olabileceği düşünüldü. Hastaya PLEVA tedavisi için Doksisiklin 200 mg/ gün başlandı. 3 aylık tedavi sonrası lezyonlar postlezyonel hiperpigmentasyon ve yer yer atrofik skarlar bırakarak geriledi. 


\section{TARTIŞMA}

PLEVA, özellikle gövde ve kolların fleksör yüzlerinde, nekrotik lezyonları da içeren papülo-veziküllerin ortaya çıkması ile karakterizedir. Bazen erüpsiyon tüm vücuda yayılabilir. Müköz membran tutulumu oldukça nadirdir. Lezyonlar iyileşirken hipohiperpigmentasyon veya varioliform skar bırakabilir (6-8). Farklı evredeki lezyonların birarada bulunması tanı için önemli bir ipucudur $(5,8)$. Hastalık her yaş grubunda ortaya çıkabilmekle birlikte, 2-3. dekadlarda ve erkeklerde daha sık görülme eğilimindedir (5).

Hastalığın etyolojisi tam olarak bilinmemekle birlikte enfeksiyon ajanları tarafından tetiklenen inflamatuar bir reaksiyon, $\mathrm{T}$ hücre diskrazisine sekonder gelişen inflamatuar bir yanıt veya immun kompleks aracılı bir hipersensitivite reaksiyonu olabileceği gibi teoriler öne sürülmektedir (5). PLEVA'ya sebep olabilecek ajanlar arasında adenovirüsler, Ebstein-Barr Virus, Toxoplasma gondii, Parvovirus B19, Staphylococcus aureus ve Streptococcus pyogenes yer almaktadır (2). Literatürde çoğunlukla Staphylococcus aureus ile gelişen bakteriyemi tabloları bildirilmiştir (9). Bizim hastamızın kan kültüründe üreyen MSSA da PLEVA gelişiminden sorumlu olabilir. Bunun hastalık öncesi var olan ve hastalığı tetikleyen bir bakteriyemi mi olduğu yoksa hastaneye yatış sonrası periferik kateter kaynaklı mı geliştiği kesin olarak belirlenememiştir.

PLEVA'nın nadir görülen ve ölümcül olabilen formu FUMHH yüksek ateş ve yaygın ülseronekrotik cilt lezyonları ile karakterizedir (5). Çoğunlukla klasik PLEVA'nın progresyonu sonucu ortaya çıkar $(5,10)$. Cilt lezyonlarına yüksek ateş, karın ağrısı, diyare, interstisyel pnömoni, santral sinir sistemi bulguları ve romatolojik bulgular eşlik edebilir. Bizim hastamızda da yüksek ateş ve artralji mevcuttu ancak başka bir sistemik tutulum bulgusu yoktu, bu nedenle klasik PLEVA olarak değerlendirildi. Ateş sonrası hastamızın lezyonlarında artış saptandı. Bu ateş MSSA bakteriyemisi sonucu olabileceği gibi, febril hastalığın bir parçası da olabilir.

PLEVA'nın tanısı klinik ve histopatolojik özelliklerin uyumuyla koyulur. Ayırıcı tanıda düşünülen hastalıklar arasında lenfomatoid papüloz, ilaç döküntüleri, Gianotti-Crosti sendromu, guttat psoriyazis, sekonder sifiliz, kutanöz küçük damar vaskülitleri, varisella ve artropod reaksiyonları yer almaktadır. Klinik olarak en sık karışan hastalık olan lenfomatoid papülozda büyük CD30+ atipik lenfoid hücrelerin olması önemli bir ayırt edici bulgudur. Diğer farkları, Reed-Sternberg hücrelerine benzeyen büyük, atipik, nonlenfoid hücrelerin ve çok sayıda nötrofilin varlığı, nekrotik keratinositlerin az olması veya hiç olmama$\mathrm{sI}$, bazal tabakada vakuolar dejenerasyonun az olması veya hiç olmamasıdır $(5,6,8)$.

PLEVA'nın tedavisinde topikal kortikosteroidler ve oral antihistaminiklerin inflamasyonu azaltmalarına rağmen hastalığın seyrini etkilemedikleri bildirilmektedir (11). Oral tetrasiklin çoğunlukla erişkinlerde tercih edilip başarılı sonuçlar alınırken, oral eritromisin pediatrik hastalarda ilk seçenektir (2). Bizim hastamızda da 200 mg/gün Doksisiklin ile 3 aylık tedavi sonrası lezyonlarda iyileşme gözlendi. Tedavide topikal takrolimus da kullanılan ajanlar arasındadır (12). PUVA ve UVB özellikle relapsların önlenmesinde faydalıdır (11). Şiddetli ve dirençli olgularda metotreksat, asitretin, dapson veya siklosporin kullanılabilir.

\section{KAYNAKLAR}

1. Gunatheesan S, Ferguson J, Moosa Y. Pityriasis lichenoides et varioliformis acuta: $A$ rare association with the measles, mumps and rubella vaccine. Australas J Dermatol 2012; 53: 76-8.

2. Ersoy-Evans S, Greco MF, Mancini AJ, Subaşi N, Paller AS. Pityriasis lichenoides in childhood: A retrospective review of 124 patients. J Am Acad Dermatol 2007; 56: 205-10.

3. Degos R, Duperrat B, Daniel F. Hyperthermic ulcero-necrotic parapsoriasis. Subacute form of parapsoriasis guttata. Ann Dermatol Syphiligr 1966; 93: 481-96.

4. Sotiriou E, Patsatsi A, Tsorova C, Lazaridou E, Sotiriadis D. Febrile ulceronecrotic Mucha-Habermann disease: a case report and review of the literature. Acta Derm Venereol 2008; 88: 350-5.

5. Fernandes NF, Rozdeba PJ, Schwartz RA, Kihiczak G, Lambert WC. Pityriasis lichenoides et varioliformis acuta: a disease spectrum. Int J Dermatol 2010; 49: 257-61.

6. Khachemoune A, Blyumin ML. Pityriasis lichenoides: pathophysiology, classification, and treatment. Am J Clin Dermatol 2007; 8: 29-36.

7. Tekin S, Türkmen M, Türk BG, Kandillioğlu G, Ceylan C. Enfeksiyon Kökenli Pitriyazis Likenoides et Varilioformis Akuta: Bir Olgu Sunumu. Türk Dermatoloji Dergisi 2009; 3: 93-6.

8. Pereira N, Brinca A, Manuel Brites $M$, José Julião $M$, Tellechea $O$, Gonçalo M. Pityriasis lichenoides et varioliformis acuta: case report and review of the literature. Case Rep Dermatol 2012; 4: 61-5. 
9. Luberti AA, Rabinowitz LG, Ververeli KO. Severe febrile MuchaHabermann's disease in children: case report and review of the literature. Pediatr Dermatol 1991; 8: 51-7.

10. Tsianakas A, Hoeger PH. Transition of pityriasis lichenoides et verioliformis acuta to febrile ulceronecrotic Mucha-Habermann disease is associated with elevated serum tumor necrosis factor-a. Br J Dermatol 2005; 152: 794-9.
11. DG Patel, Kihiczak G, Schwartz RA, Janniger CK, Lambert WC. Pityriasis lichenoides. Cutis 2000; 65: 17-23.

12. Bowers $S$, Warshaw EM. Pityriasis lichenoides and its subtypes. J Am Acad Dermatol 2006; 55: 557-72. 